\title{
Veículo de Comunicação e Gênero Textual: Noções Conflitantes*
}

\author{
(Communication Vehicle and Genre: Conflicting Notions)
}

\author{
Adair BoninI \\ (Universidade do Sul de Santa Catarina)
}

\begin{abstract}
Some textual phenomena that resemble genres (like magazines and newspapers) are commonly conceived as communication vehicles. Taking this subject as a departing point, this article examines the notions of genre and communication vehicles in order to try to determine how both have been approximated at the theoretical level. Following this line of thought, some elements are taken for the re-evaluation of the communicative and enunciative perspectives about genres.
\end{abstract}

KEY-WORDS: Genre; Communication; Enunciation; Cognition.

REsumo: Muitos fenômenos textuais que se parecem com gêneros (como as revistas e os jornais) são entendidos comumente como veículos de comunicação. Tomando este tema como um ponto de partida, o presente artigo examina as noções de gênero textual e veículo de comunicaşão para tentar determinar como ambas têm sido aproximadas no plano teórico. Nesse percurso reflexivo, são levantados elementos para a reavaliação das perspectivas comunicativa e enunciativa a respeito dos gêneros.

PaLAVRAS-CHAVE: Gênero textual; Comunicação; Enunciação; Cogniçãa.

Trabalho apresentado no VI Congresso Brasileiro de Lingüística Aplicada, que se realizou em Belo Horizonte, no período de 07 a 11 de outubro de 2001.

Agradeço as considerações preciosas das profas. Dras. Maria Marta Furlanetto e Bernardete BiasiRodrigues e assumo a total responsabilidade sobre as eventuais falhas do texto.

D.E.L.T.A., 19:1, 2003 (65-89) 


\section{Introdução}

Noções como as de código, mensagem, ruído, canal e veículo de comunicação, são tão cotidianas que poucas vezes desconfiamos do que realmente significam. De fato, a explicação clássica para a comunicação é aparentemente tão demonstrável que se torna um exercício quase imoral levantar questões contra ela.

A perspectiva comunicativa - ou o modelo de código, conforme Sperber e Wilson (1986) - está na base da própria definição do que seja a linguagem e, como tal, também as discussões sobre gêneros textuais a incorporam. Nesta perspectiva, o gênero tem sido concebido como um elemento do código, ao modo de um conjunto de recursos sígnicos que auxiliam na formatação de uma ação de linguagem.

A notícia, nestes termos, é concebida como um gênero (pois formata uma ação de linguagem, cujo propósito é comunicar a ocorrência de um fato) e o jornal, como o veículo que suporta a notícia. No entanto, se observarmos os gêneros textuais por uma ótica mais abrangente - para além do modelo de código -, poderemos concluir que "notícia" e "jornal" se conformam como gêneros encaixados e que os recursos genéricos de cada um não servem apenas para a condução de uma ação de linguagem.

A concepção da linguagem como código produz, para o gênero, uma noção pobre e limitada, que não tem sido discutida. Do mesmo modo, não se tem considerado a questão de que a base pragmática da noção de gênero não se sustenta dentro de uma visão comunicativa. Neste artigo, então, ao contrastar gênero textual e veículo de comunicação, procuro levantar elementos para uma reavaliação do papel da teoria da comunicação na definição do fenômeno linguagem, principalmente a partir das incoerências que esta teoria produz na noção de gênero.

Nas seções que se seguem, serão tratados: i) a relação entre os estudos lingüísticos e a teoria da comunicação; ii) o modo como a noção de veículo se desenvolveu na teoria da comunicação; iii) as contradições que se explicitam do emparelhamento entre as noções de gênero textual e veículo de comunicação; e iv) as perspectivas alternativas à comunicacional para o estudo do gênero. 


\section{Lingüística Comunicativa}

A visão teórica hegemônica nos estudos lingüísticos é aquela que toma por base a teoria da comunicação. Os conceitos que fundamentam esta teoria podem ser vistos como pilares arqueológicos, uma vez que se fundem à história ocidental por dezenas de séculos, tornando-se noções do senso comum difíceis de serem contestadas, tanto pela perda das referências autorais quanto pelas dificuldades de se construir um paradigma alternativo. Desse modo, propostas divergentes convivem com ela, mas não a destituem. Conforme apontam Sperber e Wilson:

A idéia de que a comunicação é obtida pela codificação de pensamentos na forma de sons está tão arraigada na cultura ocidental que se torna difícil considerá-la uma hipótese e não um fato. Mas, incontestavelmente, o modelo de código da comunicação verbal não passa de uma hipótese, com méritos bem conhecidos e defeitos nem tão bem conhecidos (1986: 17).

A explicação da atividade simbólica do homem mediante sistema de comunicação conduz à concepção de que a língua se comporta, essencialmente, na forma de um código, como conjunto de elementos manipuláveis possibilitadores da produção da mensagem. Esta concepção, dominante nas pesquisas, se reflete nos diversos manuais de introdução à Lingüística, dentre os quais se podendo citar o exposto em Lyons (1987: 28):

Um sinal é transmitido de um emissor para um receptor (ou grupo de receptores) através de um canal de comunicação. O sinal terá uma determinada forma e passará um determinado significado (ou mensagem). A conexão entre a forma do sinal e o seu significado é estabelecida pelo que (num sentido bastante geral do termo) normalmente se chama em semiótica o código: a mensagem é codificada pelo emissor e decodificada pelo receptor.

Esta concepção se reflete também nos livros didáticos, onde via de regra se toma por base o sistema de comunicação de Jakobson (1960) [fig. 1]. Este modelo, que relaciona funções da linguagem a componentes da comunicação, é o mais conhecido e citado no campo dos estudos lingüísticos.

Apesar de Jakobson não as ter incluído em seu modelo, as noções de ruído e veículo também são correntes na área. Foram incorporadas ao senso comum, de modo que não geram desconfianças teóricas, no sentido de que não lhes é exigida sustentação argumentativa. 


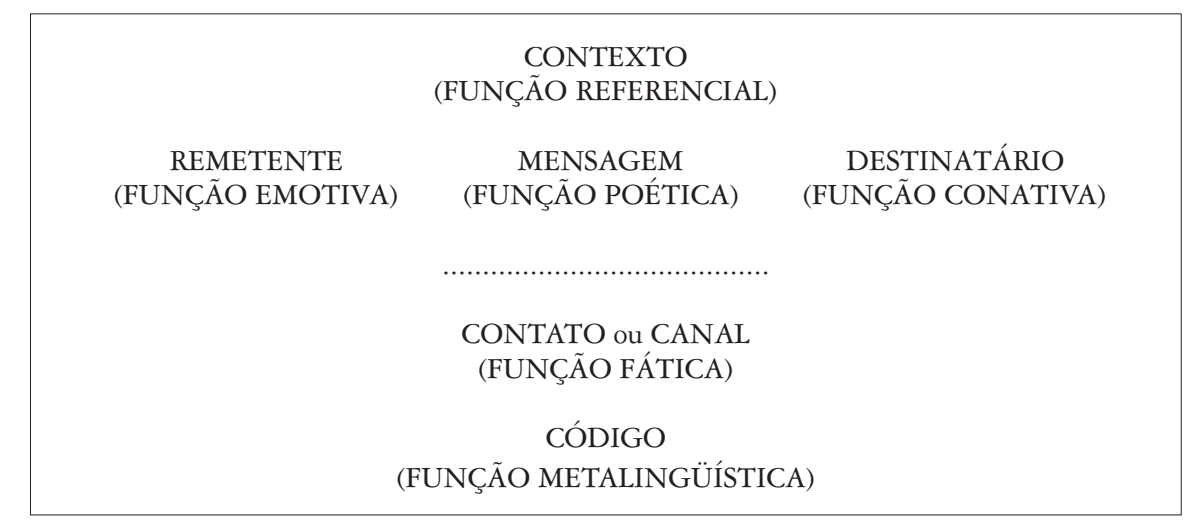

Figura 1: Sistema de comunicação de Jakobson (1960: 123).

Desde seu início, a lingüística contemporânea tem tomado por base a teoria da comunicação. Já em Saussure (1916) nos é apresentado um sistema de comunicação [fig. 2], neste período ainda de base aristotélica, sem maiores sofisticações.

A crítica de Bakhtin $(1929,1953)$ a estes modelos, principalmente ao de Saussure, foi não só um dos pontos centrais na elaboração da teoria dialógica como também um dos fundamentos para a estruturação de uma perspectiva alternativa nas pesquisas lingüísticas, os estudos da enunciação (ou a lingüística enunciativa). Ou seja, a grande divisão teórica nos estudos lingüísticos parte justamente da contestação dos pilares que compõem milenarmente a teoria da comunicação.

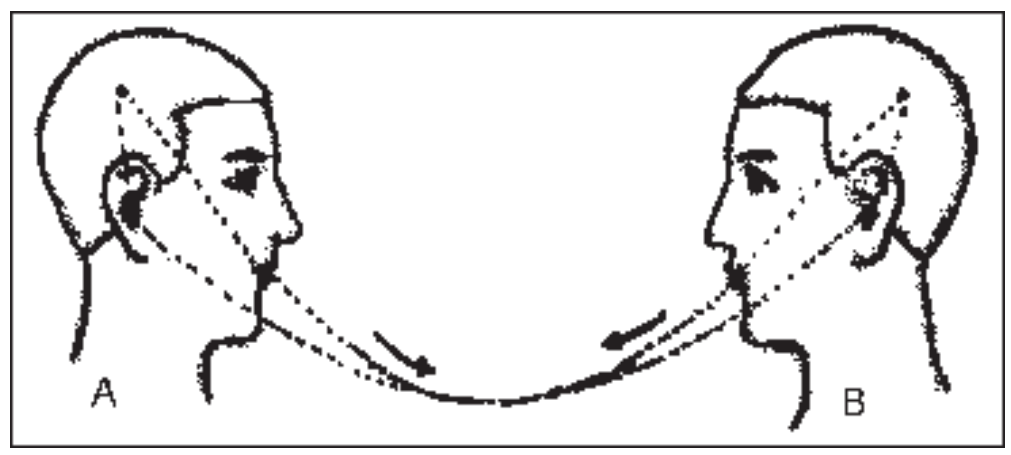

Figura 2: Circuito de comunicação de Saussure (1916: 19). 
Bakhtin viu nestes modelos um caráter idealizador do processo comunicativo, uma vez que concebem o processo de forma estável, regular e unilateral, conferindo um caráter ativo, de produção, ao locutor e passivo, de recepção, ao destinatário. Na concepção dialógica de Bakhtin, o ouvinte/leitor recebe e compreende a significação lingüística de forma ativa e responsiva, se posicionando frente ao que lhe vem de encontro. Nestes termos é que afirma: "Não se pode dizer que esses esquemas estejam errados e não correspondem a certos aspectos reais, mas quando estes esquemas pretendem representar o todo real da comunicação verbal se transformam em ficção científica" (1953: 290).

A revisão da postura comunicativa em lingüística, portanto, já apresenta toda uma discussão iniciada. Para confrontarmos as noções de gênero e veículo dentro deste panorama é necessário, contudo, termos claro como esta última noção se constitui na teoria da comunicação.

\section{Evolução dos Modelos para o Processo da Comunicação}

O marco inaugural da teoria da comunicação está firmado na "Arte retórica”, obra em que Aristóteles expõe o que veio a ser entendido como o primeiro modelo do processo de comunicação [fig. 3]. Com o objetivo de explicar o processo de convencimento de um auditório, como parte de sua teoria da argumentação, Aristóteles postula três componentes centrais para que o processo se desencadeie: o falante, o discurso e o ouvinte. Para se compreender estes elementos, no entanto, é necessário se levar em conta também a proposição aristotélica de três molduras a partir das quais o discurso se realizaria (os gêneros retóricos). É o que se pode observar nesta sua afirmação:

São três os gêneros da Retórica, do mesmo modo que três são as categorias de ouvintes dos discursos. Com efeito, um discurso comporta três elementos: a pessoa que fala, o assunto de que se fala e a pessoa a quem se fala; e o fim do discurso refere-se a esta última, que eu chamo o ouvinte. O ouvinte é, necessariamente, espectador ou juiz; se exerce as funções de juiz, terá de se pronunciar ou sobre o passado ou sobre o futuro. Aquele que tem de decidir sobre o futuro é, por exemplo, o membro da assembléia; o que tem de se pronunciar sobre o passado é, por exemplo, o juiz propriamente dito. Aquele que só tem que se pronunciar sobre a faculdade oratória é o espectador (p. 39). (grifo meu) 
Cada gênero discursivo (o judiciário, o deliberativo e o demonstrativo), portanto, define um tipo de ouvinte, ao lhe impor uma situação de discurso com comportamentos mais ou menos previsíveis. A produção do discurso, com o manejo dos silogismos retóricos (os entimemas), se daria em função de se prever a reação do ouvinte de determinado gênero, no sentido de se buscar a forma mais efetiva de persuasão.

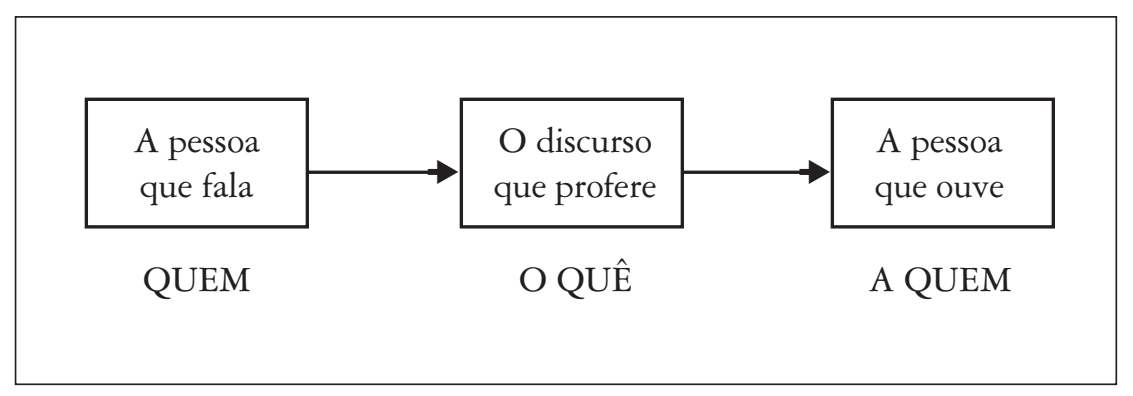

Figura 3: Sistema de comunicação de Aristóteles (cf: Aristóteles).

Diferentemente dos trabalhos retóricos produzidos até então, pautados na apresentação e no ensino de estratégias de convencimento, a "Arte retórica" se mostra como a primeira tentativa de sistematizar um campo de estudo da argumentação. Nestes termos, a proposição desse quadro conceitual não visava compor, à primeira vista, uma explicação do processo de comunicação. Foi, contudo, a base a partir da qual se erigiu, no século passado, em uma série de modelos explanatórios, a teoria da comunicação e o conceito mais comum de comunicação.

$\mathrm{Na}$ década de 30, a tentativa de Lasswell de mapear o processo de comunicação ganha notoriedade (cf: Araújo, 2001; Gomes, 1997). Retomando as idéias seminais latentes na "Arte retórica", formula um modelo mais técnico [fig. 4], em que uma das novidades é a introdução da noção de canal. Ou seja, esta formulação confere um lugar para o discurso ao postular uma base física para sua fixação e condução entre produtor e receptor. Introduz também a noção de "efeitos", que se produzem pelo que é dito. A introdução dessa noção resulta da posição de Lasswell de que a comunicação não se define somente como transferência, mas também como influência. 


\begin{tabular}{cccccc} 
QUEM diz & O QUE & & & & \\
1 & 2 & 3 & 4 & \\
& & & & & \\
\hline
\end{tabular}

Figura 4: Sistema de comunicação de Lasswell (cf: Lasswell, 1948).

A noção de canal, por sua vez, foi conduzida a um extremo de tecnicidade no modelo de Shannon e Weaver (1949). Trata-se de um trabalho que, baseado em princípios matemáticos, estrutura a teoria da informação, para especificar circuitos de comunicação em aparelhos, bem como para auxiliar na engenharia destes circuitos.

Neste modelo [fig. 5], o mais influente de todos, a informação é entendida como a medida da liberdade de escolha na seleção de uma mensagem, não devendo ser confundida com significado. Quanto mais informativo for o sinal, menos ele informa. Ou seja, a informação consiste na redução da riqueza informacional do contínuo físico. Por isso é que uma interferência no sinal representa um aumento da riqueza informacional e um prejuízo à informação. Ou seja, uma interferência que eleva a taxa informacional é caracterizada como um ruído.

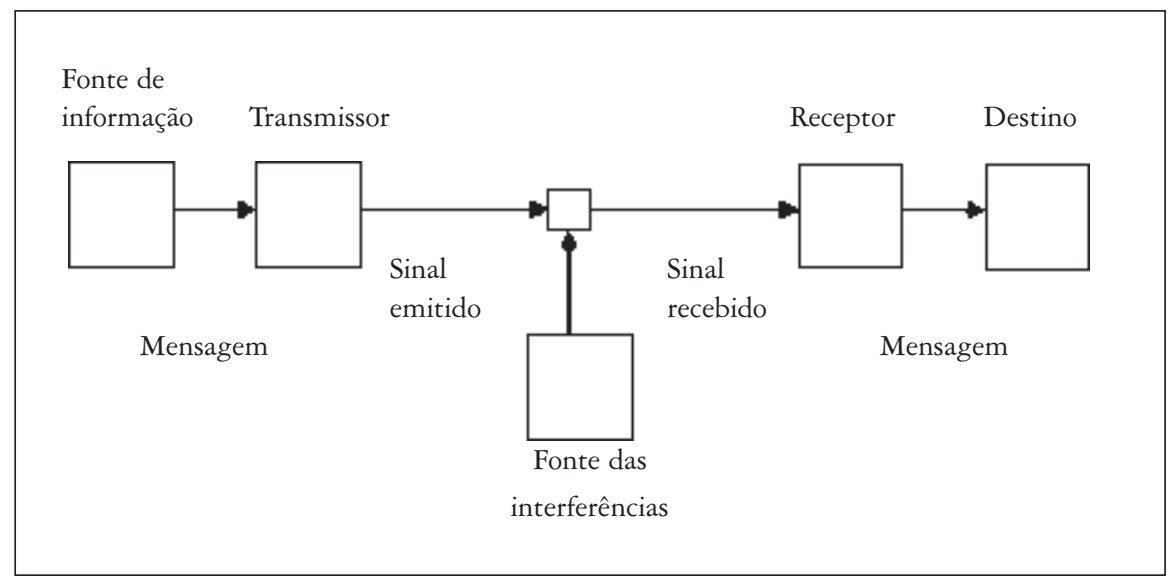

Figura 5: Sistema de comunicação de Shannon e Weaver (1963: 7). 
O modelo de Shannon e Weaver apresenta cinco componentes, sendo eles:

1) Fonte de informação: produz uma mensagem (ou seqüência de mensagens) a ser comunicada ao terminal receptor; opera em função das possibilidades do transmissor disponível (ex. uma seqüência de letras em um sistema telegráfico);

2) Transmissor: opera sobre a mensagem de modo a produzir um sinal apropriado para a transmissão através do canal;

3) Canal: o meio usado para transmitir o sinal do transmissor para o receptor (um par de fios metálicos, uma faixa de freqüências de rádio, um raio de luz, etc.);

4) Receptor: reconstrói a mensagem a partir do sinal;

5) Destino: pessoa (ou coisa) para quem a mensagem foi dirigida.

A noção de cálculo informacional, bem como o desenho básico deste sistema, foram retomados em inúmeros outros modelos. Vou me ater, contudo, somente ao modelo de Berlo (1960), uma vez que o mais importante neste momento é refletir sobre o modo como a noção de veículo foi concebida.

O grande desafio dos estudiosos posteriores a Shannon e Weaver era conseguir adaptar o modelo para explicar a comunicação humana. Seguindo este intuito, Berlo concebeu um modelo adaptado, composto de seis componentes definidos do seguinte modo:

1) Fonte: necessidades, intenções, informações e objetivos de uma pessoa que dão origem a uma mensagem;

2) Mensagem: a informação a ser transmitida, a idéia;

3) Codificador: o módulo que ordena sinais para compor a mensagem;

4) Canal: o intermediário, o condutor da mensagem;

5) Decodificador: atribui sentido às unidades do sinal, delineando a mensagem;

6) Receptor: recebe e julga a pertinência da mensagem. 
Em síntese, este modelo pressupõe que o conteúdo intencional é codificado como mensagem por um emissor através da articulação de elementos do código lingüístico, sendo esta mensagem, por sua vez, conduzida por um canal a um receptor que fará a operação de codificação ao contrário, extraindo, assim, o conteúdo dessa mensagem.

O aspecto mais relevante (e talvez mais controverso) deste modelo, quanto ao assunto aqui tratado, é o modo como define canal, especificando este componente em três sub-conceitos:

1) Mecanismo de ligação (o que mais comumente se denomina canal):

- audição, visão, paladar, tato, olfato, etc.

2) Veículo:

- primário (meios físicos): onda sonora, fóton, sabor, sensação, odor etc.;

- secundário (meios públicos): rádio, telefone, telégrafo, jornais, filmes, revistas, o palco, as tribunas públicas, reunião, memorando, aula, etc.

3) Transportador: o ar, a água, a terra, etc.

A delimitação dos componentes do modelo e a explicação do modo como funcionam trazem implícitas duas grandes contradições. A teoria mostra dificuldades para sustentar o caráter discreto destes componentes e para explicar, em um mesmo quadro conceitual, os fenômenos externos (físico) e interno (cognitivo) da comunicação.

Muito embora Berlo afirme que "(...) todos os ingredientes e fatores da comunicação (...) estão entrelaçados” (p. 73), há, nesta formulação, uma premissa de que tais componentes possam ser claramente detectados e diferenciados uns dos outros. Esta delimitação dos componentes, contudo, revela sua fragilidade, pois os critérios de especificação se misturam. Isto ocorre, primeiramente, quanto à caracterização da noção de canal que vai entrar no campo do componente código. Se o canal é um meio físico que transporta a mensagem, não se pode dizer, estritamente, o mesmo do jornal, da reunião, pois trazem consigo elementos convencionais próprios do código. Como componente psicológico de formatação e decupagem da mensagem, no código também intervêm os meios sociais de condução des- 
sa mensagem. Tudo o que é concebido como veículo não pode ser visto estritamente dentro da noção de canal.

O código (que correspondente à linguagem em Berlo) é pensado como "tudo o que contém um grupo de elementos (o vocabulário) e um conjunto de métodos para combinar esses elementos de forma significativa (a sintaxe). A concepção que se tem de linguagem hoje, contudo, inclui tanto os modos de composição da mensagem, como a própria mensagem e o meios de sua transmissão (inclui o que se enuncia e até mesmo o que se deixou de dizer/expressar).

A discretização dos componentes se invalida também quando Berlo considera as capacidades perceptuais (visão, audição, tato, etc.) como componentes do canal e ao mesmo tempo do decodificador. Diz: “(...) podemos considerar os canais de comunicação como sendo as habilidades motoras do codificador e as habilidades sensórias do decodificador (...) falamos sobre os mecanismos sensórios do indivíduo tanto na condição de canais como na de decodificadores" (p. 70-71).

A separação dos componentes da comunicação se sustenta somente quando se considera canais muito específicos (o som, p. e.) e quando se tem uma concepção de linguagem limitada aos níveis baixos da língua (fonemas, morfemas, sintagmas).

A segunda contradição visível no modelo diz respeito à distinção externo/interno ao indivíduo. É muito difícil se conseguir tratar um objeto científico ao mesmo tempo como externo e interno à mente, mesmo com uma teoria-ponte. Seria mais produtivo, neste caso, se optar por uma explicação puramente psicológica (considerando-se os meios físicos também como componentes da cognição e, portanto, da linguagem) ou puramente social (considerando-se a linguagem como um produto cultural que circula de determinado modo em certos canais e meios sociais). No presente artigo, opto pela primeira perspectiva.

Nas duas seções que se seguem, busco discutir duas teses. Na próxima, procuro demonstrar que não há como separar gênero e veículo, embora haja certo nível de distinção, e seja importante considerá-lo. Na seção seguinte, procuro apontar argumentos em favor de uma abordagem enunciativa dos gêneros em detrimento da perspectiva comunicativa. Esta posição será pensada, no entanto, como enunciativismo fraco, intermediário às concepções de sujeito logocêntrico e assujeitado. 


\section{Confrontando as Noções de Veículo e Gênero a partir do Modelo de Berlo}

A noção de gênero (textual/discursivo) é concebida pela maioria dos estudiosos (se não pela totalidade) dentro da moldura da teoria da comunicação. Neste caso, procura-se manter nítidas as distinções entre canal e código, entendendo-se o gênero como um componente do código. Vejamos como isso se explicita em duas das definições de gênero mais comunicacionistas. A primeira delas, de Swales, afirma o seguinte:

Um gênero compreende uma classe de eventos comunicativos, cujos exemplares compartilham os mesmos propósitos comunicativos. Estes propósitos são reconhecidos pelos membros especialistas da comunidade discursiva de origem e, portanto, constituem o conjunto de razões (rationale) para o gênero. Estas razões moldam a estrutura esquemática do discurso e influenciam e limitam (constrains) a escolba de conteúdo e de estilo (1990: 58). (grifos meus)

No mesmo sentido, a definição de Bhatia, numa revisão do trabalho de Swales, aponta o gênero como:

(...) uma instância de realização bem sucedida de um propósito comunicativo específico, pela utilização de conhecimento convencionalizado sobre recursos discursivos e lingü̈́sticos (1993: 16). (grifo meu)

Em ambas as definições, o gênero é visto como um recurso sígnico que possibilita, a determinado indivíduo, coordenadas para a estruturação da mensagem a ser comunicada. Neste sentido é que o gênero é pensado como uma ação de linguagem (Miller, 1984), mas via formatação definida no código. Ou seja, como um elemento convencionado, como componente do código, ele conduz estruturalmente uma ação de linguagem, ao desenvolver formalmente a intenção comunicativa de um indivíduo (a mensagem).

Desse modo, mantido nos limites da ação individual e na esfera do código, o gênero pode ser discernido do veículo, que se encarregaria de transportá-lo, servir de suporte, e que seria mais físico e menos convencionado. Estabelecida desse modo, a noção não destrói o edifício conceitual da teoria da comunicação.

Nesse sentido é que os gêneros analisados até o momento mantêm-se em conformidade com a teoria da comunicação, conservando intocada a 
distinção veículo/código. Gêneros como a carta de promoção de vendas (Bhatia, 1993) e o artigo científico (Swales, 1990) estão na esfera da ação individual, podendo ser vistos como elementos para a formatação da ação de linguagem. Quando consideramos gêneros coletivos (como a entrevista, as formas de diálogos, ou mesmo o jornal, o filme) já não estamos mais nos limites de uma ação única e de uma intenção única. Neste caso, o poder explicativo dessa conceituação comunicativa diminui. Mais difícil, ainda, é explicar o processo de encaixes em que os gêneros estão envolvidos, pois em uma peça de linguagem como o jornal as noções de gênero e veículo se sobrepõem mutuamente, mostrando que o gênero não está só na esfera da ação humana individual e que não funciona somente como um codificador dessa ação.

Código e veículo podem ser elementos mais ou menos distintos quando se pensa em um sistema simples de comunicação (como a conversação face a face) e quando não se vai além dos níveis baixos da língua, onde as unidades (fonema, morfema, sintagma) podem ser, de certo modo, discretizáveis. Em relação ao gênero, contudo, se há possibilidade de discretização, nem sempre será com base nos mesmos procedimentos. Não há como separar nitidamente meio físico de ocorrência, valores culturais implicados e estrutura lingüística e, por isso, gênero e veículo se fundem em muitos contextos. Vejamos o exemplo do jornal:

Na figura 6, podemos observar, em uma aplicação do sistema de comunicação de Berlo, o percurso de uma reportagem, desde sua produção pelo repórter até sua recepção por um leitor. Torna-se claro, aqui, que as noções de gênero e de veículo se fundem em determinado ponto do processo. Fica difícil dizer que o jornal é somente um veículo. Vejamos as etapas desse processo:

1) Inicialmente, um jornalista (F1) escreve uma reportagem, codificando-a lingüisticamente (Co1) e transmitindo-a para o editor do jornal por meio de um veículo escrito (V1);

2) Em uma segunda etapa, o editor (F2) vai editar (Co2) a reportagem $(G)$, incluindo-a em uma sessão ou suplemento (V2), que comporá o todo do jornal (V3);

3) Ainda como etapa de construção da mensagem, o jornal será diagramado (Co3) e impresso (V4);

4) Só então, o leitor receberá visualmente $(\mathrm{Ca})$ a mensagem na forma de jornal, passando, então, a decodificá-la lingüisticamente (De). 


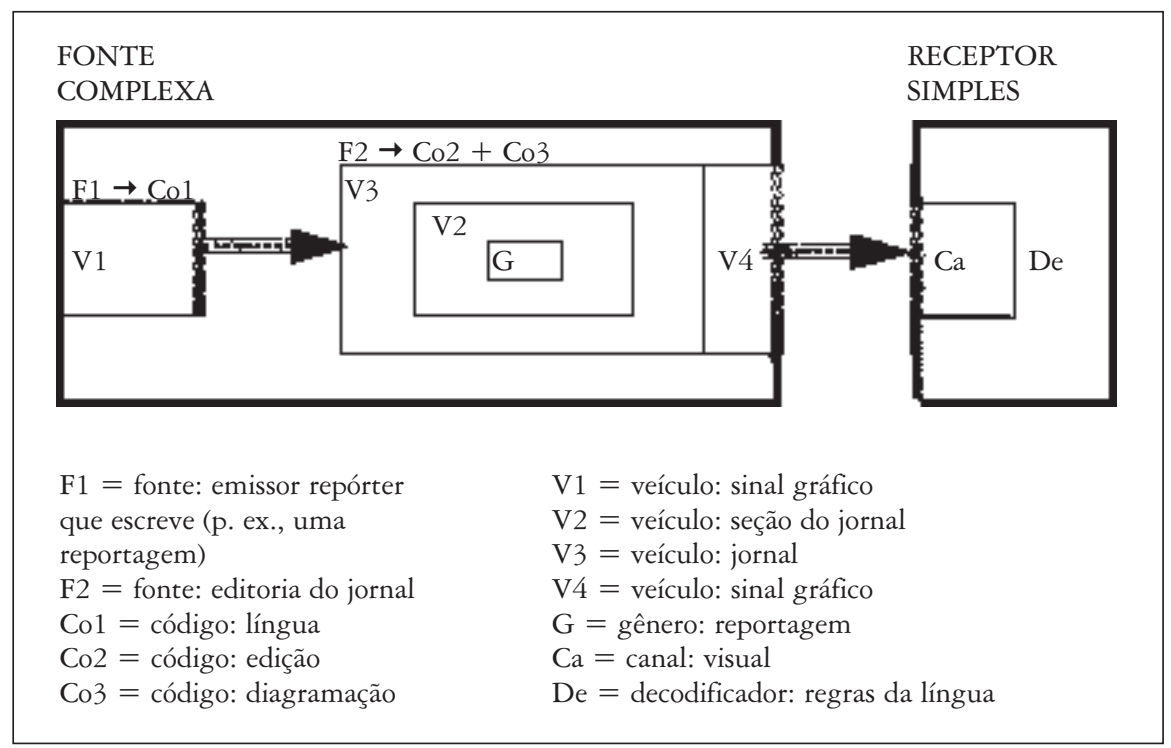

Figura 6: Sistema de comunicação que perfaz o jornal.

É interessante notar que, na etapa dois, o veículo passa de uma modalidade física (o sinal gráfico em papel) para uma convencional (o jornal), dois objetos ontologicamente bastante distintos. O confronto mais nítido, no entanto, é entre as noções de gênero e veículo.

Se o jornal é um veículo, pode-se inferir que suas partes também são veículos, uma vez que o leitor pode optar por ler uma seção ou outra, mas dificilmente o jornal como um todo. Entretanto, se se conclui que determinada seção encaixada no jornal é um veículo, deve-se concluir que o gênero encaixado no jornal também o é. Diga-se de passagem que o próprio jornalista já escreverá a reportagem tento em vista toda esta estrutura de encaixes.

Se o jornal e a seção do jornal são veículos, o gênero, como parte de uma seção, também deveria ser entendido como um veículo. Isso, contudo, implica em dizer que os gêneros não existem no jornal. Por outro lado, se poderia assumir o pressuposto de que, sendo o gênero um material sígnico relativamente compartilhado entre os membros de determinada comunidade, e que, tendo o jornal a mesma propriedade cultural e sígnica do gênero, ele seria também um tipo de gênero e não um veículo propria- 
mente. Se assumirmos o ponto de vista de que a teoria da informação (Shannon e Weaver) não é uma moldura adequada para se pensar a noção de gênero, o jornal também pode ser entendido como um gênero construído a partir do encaixe de outros, um hiper-gênero.

Ao que tudo indica, na realização das condutas humanas, não há uma clara distinção entre o aparato lingüístico e o não lingüístico. A noção de gênero, por incorporar aspectos pragmáticos da linguagem (já que este é pensado como a base representacional de um tipo de ação de linguagem), implode a noção de comunicação como manipulação de elementos discretos de um código. Ou seja, está implicado no conceito de gênero, de certa forma, que o homem está imerso na linguagem.

Este dano à posição clássica, então, também coloca questões à própria teoria dos gêneros da escola anglo-saxã (Swales, Bhatia, Biber), devido à sua orientação eminentemente comunicacional. É possível que não haja uma relação direta entre estruturação lingüística do texto (superestrutura) e ação de linguagem, mas que elementos diversos sejam considerados: i) pela sua relevância social, de acordo com uma complexa estrutura de razões; e ii) pela sobreposição de valores estruturais, no sentido de que para cada ponto de saliência há um campo circundante de sobreposições estruturais. Entre estes elementos, se pode citar, como intervenientes na constituição dos gêneros e no modo como se distinguem entre si: o suporte físico da enunciação (conferência, teleconferência, videoconferência); a estrutura de encaixe da/s enunciação/ões (resumo e artigo científico); o papel social do enunciador (editorial, artigo assinado); o/s propósito/s do/s enunciador/ es (notícia, crítica), a estrutura textual propriamente (conto e romance).

Em outras palavras, o gênero corresponde a um conjunto de elementos decorrentes de um processo de especificação significativa, que são recorrentes para uma ação de linguagem no sentido de interação, mas não necessariamente de comunicação. Desse modo, nem o propósito, nem a organização retórica (estrutura textual) podem ser considerados como elementos centrais na identificação ou na constituição dos gêneros. Consideremos dois exemplos.

Primeiramente, no jornal, o que diferencia o editorial, a opinião do leitor e o artigo assinado? Ao que parece, a identidade de cada um desses gêneros é cunhada mais pela posição de onde se fala (editorialista, leitor especialista e articulista), pelo que está envolvido nesta posição, do que pela 
estruturação lingüística destes gêneros, que é praticamente a mesma. Mesmo o propósito, se não nos ativermos a uma especificação mediante o papel social do enunciador, será praticamente o mesmo: convencer pela argumentação. Um segundo exemplo seria o da distinção entre o texto de chamada de capa e o texto da notícia, que têm relações diretas de conteúdo e forma. O que vem a ser relevante nesse caso? Embora haja sutis diferenças no plano da estruturação textual, o que realmente distingue um do outro é o processo que estrutura o jornal, onde a chamada (sumarizando a notícia e vindo na capa) serve como um endereçamento ao conteúdo do jornal, mas também como um excitador para que o leitor compre o jornal.

Considerando estes dois exemplos, podemos supor que não é só a possibilidade de conduzir estruturalmente uma ação de linguagem e desenvolver a intenção comunicativa de um indivíduo que delimita o que seja gênero. Muitos gêneros cotidianos, como a passagem, o ingresso, o plano de aula, a lista de compras, não formatam uma ação de linguagem e nem têm como primeira função comunicar algo. Suas funções são mais instrumentais, de organização e apoio para a realização de uma ou várias ações de linguagem ou mesmo de uma ação social pura. A identidade do gênero pode emergir da própria saliência em um processo complexo de interação, o que permite ver os textos que compõem o jornal como gêneros encaixados e o próprio jornal como um hiper-gênero formado por estes gêneros encaixados e por outros mecanismos (como a manchete, o chapéu, o olho, o sele, etc.).

Neste contexto, cabem algumas observações. Primeiramente, o termo suporte (já bastante utilizado na literatura) se revela mais produtivo que o termo veículo. Não implica em uma separação nítida entre linguagem e base física transportadora.

Em segundo lugar, embora gênero e suporte não se separem completamente, pode-se construir uma distinção, considerando-se este contínuo. Neste caso, o suporte pode caracterizar os dispositivos mediante os quais os gêneros circulam. Ambas as noções, assim, podem ser aplicadas a um contínuo, de tal modo que, por exemplo: 1) a quarta capa, vista como gênero em Cristóvão (2002), seria melhor caracterizada como suporte, uma vez que nesta seção de um livro podem ser alocados vários tipos de gênero; 2) o editorial, pode ser visto como suporte e gênero, ao mesmo tempo, pois é tanto uma seção específica do jornal quanto um fenômeno de lin- 
guagem específico; e 3) a notícia é um gênero em estado mais puro, pois circula em vários suportes (televisão, jornal, e, no jornal, em seções como as de política, economia, esportes, etc.).

\section{Lingüística Enunciativa e Gênero}

Como alternativa à visão comunicativa, apresenta-se a visão enunciativa, tradicionalmente identificada como a escola francesa de estudo da linguagem. Na perspectiva comunicacionista, o sujeito tem o poder absoluto sobre o seu dizer. Este dizer, assumido como simétrico ao enunciado produzido, está envolvido em uma dinâmica onde o sujeito A especifica os estados do sujeito B mediante a transmissão de uma informação. A perspectiva enunciativista se mostra como alternativa na medida em que destitui o poder intencional do sujeito colocando-o como determinado por uma exterioridade. Neste sentido, rompe o processo especificatório entre sujeitos ao focalizar a enunciação, entendida, nesse caso, como o processo de funcionamento da linguagem pelos recursos que incidem sobre o dizer de um sujeito.

Ao apontar uma perspectiva enunciativa, entretanto, não pretendo afirmar que ela se constitui em um bloco monolítico. Existem posições divergentes, de modo que se pode ter um enunciativismo puro, em que todo o funcionamento lingüístico é explicado pela exterioridade e o sujeito é totalmente determinado pelo discurso, e também propostas que, embora levem em conta a divisão do sujeito, vêm aí a possibilidade de se considerar os estados intencionais. Possenti (1995), por exemplo, embora assuma que o sujeito não seja a origem do dizer, mas um efeito, afirma que: "Só uma falha radical de lógica pode fazer equivaler 'o sujeito é dividido' ou 'o sujeito é efeito' a 'o sujeito não existe”' (p. 47). A partir dessa posição, busca exemplos para confirmar a presença de estados intencionais na enunciação, o que ele denomina a "subjetividade mostrada" (a presença do "eu" no discurso do "outro"). Um dos exemplos que utiliza é a frase extraída do humorístico Planeta Diário, v. 15, n. 58: "O Senor é meu pastor e nada me faltará". Esse enunciado faz referência à jogada política de venda de um pequeno partido, de um candidato a outro popularmente conhecido como Sílvio Santos, mas cujo nome de registro é Senor Abravanel. Possenti afirma que, nesse caso, embora através do discurso do outro, podese ver que o "eu" deixa uma marca da sua presença quando altera o enun- 
ciado. Chega, então, à seguinte reflexão: "Qual é a instância responsável por essa novidade? Por que não reconhecer um eu com um papel ativo nestes textos, responsável pela alteração produzida sobre e a partir do discurso do outro? Para tanto, não é necessário, evidentemente, supor que tal 'eu' seja uma instância livre e independente de quaisquer condições” (p. 51).

Outro trabalho com posicionamento crítico sobre o isolamento do sujeito em uma enunciação totalmente exterior é o de Fulanetto (2000). A autora parte da constatação de que as constantes incursões de outras disciplinas ao campo da $\mathrm{AD}$ (a pragmática, por exemplo) faz com que ela tente circunscrever o seu campo pela negação de certas facetas da linguagem. Uma dessas facetas é justamente a presença de estados intencionais no sujeito. Questiona:

Neste ponto pode-se até chegar a conclusão de que a $\mathrm{AD}$ (ou melhor, alguns mentores) inscreve a opção de não tratar todos os sujeitos - talvez seja melhor dizer: a opção de não tratar de todas as facetas do sujeito. Ela prestaria atenção apenas na parte do sujeito que é efetivamente assujeitada. Mas que tipo de conflito teríamos nesse caso? Tudo não seria harmonioso e não tão heterogêneo? (p. 196)

É justamente este ponto que me interessa discutir e, para isso, vou citar mais um trecho do artigo de Possenti: "Ora, é má lógica pensar que (...) torna-se obrigatório deixar ao outro todo o lugar e todos os papéis. Voltaríamos à simplificação de antes, apenas invertida" (p. 52). Ao postular a enunciação como um processo exterior ao sujeito, o enunciativismo francês, embora alcance solução para os principais problemas da perspectiva comunicacionista (o logocentrismo do sujeito e o processo codificação/ decodificação), acaba mantendo uma visão de linguagem muito próxima daquela. Em ambas as perspectivas a linguagem equivale a produto cristalizado. Ou seja, embora no enunciativismo se busque entender o processo de constituição histórica da linguagem e se alcance, assim, uma explicação do espaço da sua dinâmica (em metáforas como a da cristalização), não se chega a explicar propriamente a dinâmica. Tem-se como resultado, ainda que por um outro olhar, o produto cristalizado. O sujeito não segue regras, mas está determinado por um já dito.

Tomemos como exemplo o trabalho de Ducrot (1984) sobre polifonia (que não é um dos mais radicais nesse campo). Ao postular os conceitos de enunciador, enunciatário, locutor, alocutário, enunciação, enunciado, sig- 
nificação e sentido, alcança um modo de descrever a enunciação. Contudo, ao definir a significação de uma conjunção (o caso clássico do "mas", por exemplo), mediante conceitos como significação e sentido, volta ao âmbito da linguagem como elemento cristalizado, já que tem como produto final a descrição de um rotina consensual própria de um grupo, mas não o modo como o "novo" ganha existência, a partir dessas rotinas. O trabalho de Ducrot, neste caso, é uma descrição do "dito", mas não do "dizer". Como aparelho teórico, aponta novos elementos para se discutir a visão de linguagem posta, mas não propriamente para redefini-la.

Em termos da discussão da noção de gênero, nesta linha de reflexão, três autores têm se destacado: Maingueneau (1991), Adam (1992, 1999) e Bronckart (1987, 1997). De modo muito próximo à visão comunicativa, também aqui o gênero acaba por ser entendido como um recurso cristalizado pelo o qual o indivíduo se guia para produzir o seu enunciado e realizar uma ação de linguagem. Note-se, por exemplo, o que afirma Bronckart (o trabalho que mais se enquadra nesta caracterização):

Defendemos (...) que, no nível de um agente particular, a produção de um novo texto empírico deve ser concebida como o resultado de uma colocação em interface das representações construídas pelo agente sobre a situação de ação (sobre os motivos, intenções, conteúdo temático a transmitir, etc.) e das suas representações sobre os gêneros de textos indexados disponíveis no interdiscurso. Nessa visão, todo novo texto empírico, portanto, é necessariamente construído com base no modelo de um gênero, isto é, ele pertence a um gênero. (p. 138) (Grifos meus)

No caso de Maingueneau, a reflexão se processa de um modo diferente, pois dá margem a uma visualização do processo de constituição tanto do gênero quanto da novidade na linguagem. Esta novidade, entretanto, é regida pelo arquivo como processo exterior ao indivíduo. As necessidades imediatas não são contempladas como pertencentes ao falante; as atividades de linguagem que decorrem dessas necessidades não são vistas como atos criativos, mas como determinações do arquivo. Maingueneau fala do gênero como envolto em uma atividade mais ou menos ritualizada. Diz ainda: "não podemos interpretar um enunciado se não sabemos a qual gênero relacioná-lo” (1998: 75). Mas haveria uma forma pronta para cada tipo de necessidade enunciativa cotidiana? O que dizer das enunciações que não revelam ligação com um gênero, que não re(a)presentam ações ritualizadas, e dos gêneros que funcionam como conjuntos de enunciações 
ou de conjuntos de enunciações que não revelam um gênero (ou um gênero específico)?

Ao ver o gênero como o que é cristalizado (disponível no interdiscurso ou como dispositivo do arquivo), perde-se de vista toda uma gama de textos que não apresentam identidade fixa, que não sendo exemplares de um gênero, ocorrem simplesmente como uma enunciação construída sobre (e sobre a qual incidem) várias fontes. É o caso, por exemplo, de uma publicação em formato de revista que é instituída especificamente para divulgar uma linha de produtos. Trata-se da publicação "Audi Magazine", que não é nem uma revista propriamente, nem um panfleto de propaganda. Não se pode dizer que esta publicação seja um exemplar de um gênero disponível no interdiscurso e nem que ela se tornará um gênero. A dinâmica enunciativa se constitui em virtude de um novo pretendido (não linguagem) através de um dado ou quase-dado (linguagem). Uma teoria completa da enunciação necessitaria explicar, além da linguagem, o que é quase linguagem e o que não é linguagem: não ter o conceito de linguagem como garantido. Esta questão tornou-se evidente nos estudos dos gêneros e tem me impulsionado a uma reflexão sobre os textos não marcados por um gênero, mediante a noção de pré-gênero (Bonini, 2001a) e sobre os tipos de restrições formais genéricas que incidem sobre a produção do enunciado (Bonini, 2001b, 2002). Bhatia (1997) discute esta questão, embora de um ponto de vista pragmaticista. Para ele, "embora os gêneros sejam tipicamente associados a contextos retóricos recorrentes e sejam identificados com base em propósitos comunicativos compartilhados (...) eles são construtos dinâmicos”, com duas facetas que a princípio parecem contraditórias: o aspecto convencional e a tendência à inovação. Bakhtin (1954) também toca esse ponto, quanto afirma que:

As formas do gênero às quais modelamos nossa fala se distinguem substancialmente das formas da língua, do ponto de vista de sua estabilidade e de suas leis normativas para o locutor. De um modo geral, elas são mais maleáveis, mais plásticas e mais livres do que as formas da língua. (p. 302)

Não que o gênero em si não seja resultado de um processo de cristalização, mas sua dinâmica enunciativa não é movida nesta direção. O enunci-

1 Audi Magazine, São Paulo, Premissa Editora e Publicidade, v. 6, n. 36, 2001. 
ado não se dá exclusivamente como exemplar de um modelo, mas como enunciação que reinventa o modelo ou constrói um novo, dadas as necessidades enunciativas que se configuram no sujeito pelo condicionamento externo e pela sua vontade. Nesse momento, é pertinente citar um trecho que revela a noção de enunciação de Bakhtin (1929: 92):

\footnotetext{
$\mathrm{Na}$ realidade, o locutor serve-se da língua para suas necessidades enunciativas concretas (para o locutor, a construção da língua está orientada no sentido da enunciação da fala). Trata-se, para ele, de utilizar as formas normativas (admitamos, por enquanto, a legitimidade destas) num dado contexto concreto. Para ele, o centro de gravidade da língua não reside na conformidade à norma da forma utilizada, mas na nova significação que essa forma adquire no contexto. (...) Para o locutor, a forma lingüística não tem importância enquanto sinal estável e sempre igual a si mesmo, mas somente enquanto signo sempre variável e flexível. (grifo meu)
}

Voltando as críticas endereçadas ao enunciativismo radical, Furlanetto (2000) sugere a inclusão de uma psicologia na AD, fazendo menção à teoria Vygostskyana. Mais que isso, eu diria que é possível se pensar um enunciativismo "fraco", um projeto que pode ser iniciado a partir das proposições de Maturana. Sua teoria autopoiética explica a linguagem e a cognição como resultantes da atividade autônoma de um indivíduo. Ao pensar a autonomia do humano como um processo de constituição mútua e a cada momento entre unidade e meio, Maturana concebe um sujeito clivado pelo outro. Esse outro, contudo, não é exterior, mas interpretado conforme as necessidades internas da unidade. $\mathrm{O}$ social, neste sentido, se compõe mediante redes de conexões entre as unidades, podendo estas redes ser consideradas de um ponto de vista mais específico (dentro do campo de condutas específicas de uma unidade) ou mais abrangente (a partir do que incide sobre várias redes).

Pode-se partir daí para se pensar um enunciativismo e especialmente um enunciativismo de tipo fraco. A autopoiese pode ser entendida como um tipo de enunciativismo, pois, nela, a linguagem existe como acontecer e como resultado de uma história de interações (ela também se constitui pela exterioridade). A linguagem é vista como "um operar em coordenações consensuais de coordenações consensuais de ações" (Maturana, 1998: 20). Pode-se pensar aí também um enunciativismo fraco, pois a exterioridade não é a razão única do dizer e nem a determinante. O que determina as condutas de uma unidade é a sua dinâmica estrutural que deve se manter no sentido de evitar interações destrutivas. Segundo Maturana (1978: 153): 
(...) cada elemento do comportamento de um organismo operando em um domínio consensual age como uma perturbação desencadeadora de outro. Portanto, o comportamento do organismo A perturba o organismo B, desencadeando nele uma mudança de estado interna que estabelece nele um background estrutural novo para suas interações futuras, e gera um comportamento que, por sua vez, perturba o organismo A, que... perturba o organismo B, que..., e assim por diante, de uma forma recursiva até o processo parar - seja porque, como um resultado das mudanças estruturais de A e B, algum comportamento que não pertence ao domínio consensual é desencadeado, seja porque intervém alguma interação independente que os leva para fora do domínio consensual.

Além de o "eu" ser visto como interceptado pela ação do outro (mas não determinado), nesta perspectiva, a comunicação é concebida como perturbação mútua entre pelo menos duas unidades (e não com especificação mútua e simétrica). Ou seja, o caráter enunciativista da teoria autopoiética também se mostra na redefinição da noção de comunicação. Em contraposição à visão comunicativa clássica, Maturana se opõe ao princípio de transmissão da informação nos seguintes termos:

(...) o emissor e o recebedor devem ser operacionalmente congruentes para que o fenômeno da comunicação ocorra. (...) Na verdade, cada interação pode ser descrita de maneira trivial como uma comunicação. Portanto, deve ser entendido que a visão corrente de comunicação como uma situação na qual os sistemas em interação especificam os estados uns dos outros mediante a transmissão de informação é tanto errada quanto enganosa. (1978: 155)

Há proximidade com a posição da escola francesa, mas com ganho explanatório, já que aqui, uma vez que toda interação (implicando em criatividade) pode ser entendida como comunicação, não se está recorrendo à concepção clássica de linguagem como produto cristalizado e delimitador. As unidades em interação se perturbam mutuamente e a linguagem se dá tanto como história das perturbações anteriores quanto como ocorrência de uma perturbação imediata que, nesse sentido, sempre se dá como "novo", pelo menos no sentido de reinvestimento.

No todo, a teoria autopoiética, ao conceber cognição e linguagem como fenômenos dinâmicos, possibilita, além da linguagem, a investigação do fenômeno da "quase-linguagem". Neste caso, os gêneros seriam um campo de reflexão cheio de potencialidades, pois as inovações podem ser observadas cotidianamente, mesmo que muitas vezes não se reflitam direta- 
mente nas estruturas composicionais. O estável está eminentemente interceptado pelo novo e existe em razão deste.

Uma última característica bastante relevante em relação ao fenômeno da comunicação é que esta proposta teórica elimina a incoerência da teoria da comunicação clássica a respeito dos meios externo e interno da mensagem, ao focalizar a explicação no organismo, no âmbito de sua interioridade. Adam (1999), embora trabalhando em outra perspectiva teórica, já aponta para esta realidade, quando afirma que o contexto não é um dado exterior ao sujeito, mas uma entidade cognitiva. Diz que "(...) toda interação repousa sobre a memória das interações e das falas anteriores e visa estabelecer um estado novo da memória que servirá de base a uma interação posterior" (p. 126).

Há também pontos bastante polêmicos na posição de Maturana. Um deles é sua total negação da existência de estados representacionais. Diferentemente de Magro (1999), que defende esta posição, vejo muitas dificuldades em se estudar a linguagem somente a partir da pressuposição de um "domínio relacional" (cujas bases ontológicas são de difícil demonstração). Dentro do campo das teorias de linguagem haveria, neste caso, a necessidade da adesão a um enunciativismo de tipo "forte". Por outro lado, aceitando-se a existência de estados representacionais (logicamente não no sentido tradicional de espelho do mundo), há muitos diálogos possíveis. Entre os principais candidatos para este diálogo, teríamos a teoria dos sistemas dinâmicos (van Gelder, 1997), o trabalho sobre os marcadores somáticos de Damásio (1992), a teoria da intencionalidade de Searle (1992) e, mais especificamente no campo da linguagem, a pragmática da relevância de Sperber e Wilson (1986).

De qualquer modo, é importante aqui ressaltar o crescimento do número de estudos e proposições teóricas que repensam a visão aristotélica de linguagem e da própria ciência, o que já tem sido denominado de pensamento não-aristotélico.

\section{Considerações Finais}

Considerando-se o exposto até aqui, pode-se ressaltar dois pontos principais. Primeiramente, observamos que o gênero rompe a teoria da comunicação, uma vez que: i) levantando-se o processo de encaixe dos gêneros 
no jornal, gênero e veículo se imbricam indissociavelmente; ii) ao se contemplar o caráter multi-autoral do jornal e de tudo o que o compõe, gênero não perfaz uma ação individual, no sentido de manipulação de um código, mostrando-se como o lugar a partir do qual se interage. Neste sentido, todo o meio - incluindo veículo, suporte, emissor e receptor - entra no escopo da definição de determinado gênero. Nossa ação de linguagem ocorre dentro da linguagem, mas não dentro de um veículo, porque a estrutura física da interação também é tomada como linguagem (como cognição).

O segundo aspecto a ser ressaltado é o de que a perspectiva enunciativa se apresenta como alternativa para o estudo da linguagem e, conseqüentemente, do gênero, mas é menos promissora em uma das alternativas. $\mathrm{O}$ enunciativismo forte (escola francesa de estudo da linguagem), embora tenha produzido mecanismos teóricos de revisão da perspectiva comunicacionista, não traz uma definição essencialmente diferente de linguagem, já que trabalha com o mesmo fenômeno, o cristalizado. O enunciativismo fraco (uma possibilidade a ser explorada a partir da escola chilena de estudo da cognição, principalmente através do trabalho de Maturana) produz mecanismos teóricos de revisão da perspectiva comunicacionista e de redefinição da noção de linguagem posta, uma vez que trabalha o processo na direção do novo (a perturbação) para o cristalizado (conduta consensual). Ou seja, neste caso, qualquer alteração no domínio de condutas de um grupo de indivíduos já é uma mensagem. Guardadas as diferenças há aí um diálogo possível e provável entre ambas as modalidades.

E-mail: adbonini@yahoo.com.br

Recebido em maio de 2002

Aprovado em agosto de 2002

\section{REFERÊNCIAS Bibliográficas}

Adam, Jean-Michel. 1992. Les textes: types et prototypes. Paris: Nathan. . 1999. Linguistique textuelle: des genres de discours aux textes. Paris: Nathan.

Araújo, Carlos Alberto. 2001. A perspectiva norte-americana. In: Antonio Hohlfeldt, Luiz C. Martino \& Vera Veiga França. Orgs. Teorias da comunicação: conceitos, escolas e tendências. Petrópolis: Vozes. 
Aristóteles. $A$ arte retórica e a arte poética. Trad. por Antônio P. de Carvalho. Rio de Janeiro: Ediouro. A arte retórica.

BakHTin, Mikhail. 1953. Estética da criação verbal. Trad. por M. E. Galvão Gomes. São Paulo: Martins Fontes, 1992.

. 1929. Marxismo e filosofia da linguagem. São Paulo: Hucitec, 1992.

BERLO, David K. 1960. O processo da comunicação: introdução à teoria e à prática. Trad. de Jorge Arnaldo Fortes. São Paulo: Martins Fontes, 1979.

BHATiA, Vijay K. 1993. Analysing genre: language use in professional settings. New York: Longman.

. 1997. Genre analysis today. Revue Belge de Philologie e d'histoire, 75 : 629-642.

Biber, Douglas. 1988. Variation across speech and writing. Cambridge: Cambridge University Press.

Bonini, Adair. 2001a. Em busca de um modelo integrado para os gêneros do jornal. Texto inédito.

. 2001b. Gênero textual como signo lingüístico: os reflexos da tese da arbitrariedade. Linguagem em (Dis)curso, 1(2): 123-135. .2002. Gênero textual e cognição: um estudo sobre a organização cognitiva da identidade dos textos. Florianópolis: Insular.

Bronckart, Jean-Paul. 1997. Atividade de linguagem, textos e discursos: por um interacionismo sócio-discursivo. Trad. por Anna Rachel Machado. São Paulo: Educ, 1999.

. 1987. Interactions, discours, significations. Langue Française, 74/ La typologie des discours: 29-50.

Cristóvão, Vera Lúcia Lopes. 2002. O gênero quarta capa no ensino de inglês. In: Angela Paiva Dionisıo, Ana Rachel Machado \& Maria Auxiliadora Bezerra (Orgs.) Gêneros textuais E ensino. Rio de Janeiro: Lucerna.

Damásio, Antônio. 1994. O erro de Descartes. São Paulo: Companhia das Letras, 2000.

Ducrot, Oswald. 1984. O dizer e o dito. Campinas: Pontes, 1987.

Furlanetto, Maria Marta. 2000. Problematizando o estatuto da AD. Uniletras, 22: 189-212.

VAN GELDER, Timothy. 1997. Dynamics and cognition. In: John Haugeland. Mind design II. Cambridge: Bradford Book.

Gomes, Pedro Gilberto. 1997. Tópicos de teoria da comunicação. São Leopoldo: Ed. Unisinos. 
JAKOBSON, Roman. 1960. Lingüística e poética. In: . Lingüústica e comunicação. São Paulo: Cultrix, 1991.

LAsswell, Harold D. 1948. A estrutura e a função da comunicação na sociedade. In: Gabriel CoHn (Org.) Comunicação e indústria cultural. $4^{\mathrm{a}}$ ed. São Paulo: Cia Editora Nacional, 1978.

Lyons, John. 1987. Lingua(gem) e lingüística: uma introdução. Rio de Janeiro: Guanabarra Koogan.

Magro, Cristina. 1999. Representação, Virtus Dormitiva e Linguagem. In: P. Oliveira, V. Benn-Ibler \& E. Mendes (Orgs.) Revisitações: Edição Comemorativa dos 30 anos da Faculdade de Letras. Belo Horizonte: Editora FALE/UFMG.

Maingueneau, Dominique. 1991. L'analyse du discours: introduction aux lectures de l'archive. Paris: Hachette. . 1998. Termos-chave da análise do discurso. Belo Horizonte: Editora UFMG.

Maturana, Humberto. 1978. Biologia da linguagem: a epistemologia da realidade. Trad. de Cristina Magro. In: Belo Horizonte: Ed. da UFMG, 1997. . Ontologia da realidade. . 1998. Emoções e linguagem na educação e na política. Trad. de J. F. Campos Fortes. Belo Horizonte: Ed. da UFMG.

Miller, Carolyn R. (1984) Genre as social action. In: Aviva Freedman \& Peter MEDWAY. Eds. Genre and the new rhetoric. London: Taylor \& Francis, 1994.

Possenti, Sírio. 1995. O "eu" no discurso do outro ou a subjetividade mostrada. Alfa, 39: 23-44.

SAussure, Ferdinand. 1916. Curso de lingüística geral. Trad. por Antônio Chelini, José Paulo Paes e Izidoro Blikstein. 16.ed. São Paulo: Cultrix, 1991.

SeArle, John R. 1992. A redescoberta da mente. Trad. de Eduardo Pereira e Ferreira. São Paulo: Martins Fontes, 1997.

SHANNON, Claude E. \& Warren WeAver. 1949. The mathematical theory of communication. Urbana: The University of Illinois Press, 1964.

Sperber, Dan \& Deirdre Wilson. 1986. La relevancia. Madri: Visor, 1994.

Swales, John M. 1990. Genre analysis: English in academic and research settings. New York: Cambridge University Press. 